\title{
Perceived Problem Solving Skills of Married Couples Predicting Self-Efficacy Beliefs Towards Their Marriages ${ }^{1}$
}

\author{
Arş. Gör. Seher Merve ERUS*
}

Yıldız Teknik Üniversitesi, Eğitim Fakültesi, Davutpaşa Kampüsü, Esenler / İstanbul / Türkiye

\author{
Yrd. Doç. Dr. Azize Nilgün CANEL \\ Marmara Üniversitesi, Atatürk Eğitim Fakültesi, Göztepe Kampüsü, \\ Kadıköy / İstanbul / Türkiye
}

\begin{abstract}
The purpose of this study was to determine the extent to which perceived problem solving skills of married individuals predict their self-efficacy beliefs towards marriage. The study was a descriptive study and designed according to the relational model. The population consists of married individuals who worked in and were

\footnotetext{
1 This study was derived from the Master Thesis by Seher Merve Erus, under the supervisory of Asst. Prof. Nilgün Canel, Marmara University.

* Sorumlu Yazar. Tel: +902123835577_ T-posta:smerve@yildiz.edu.tr

(C) 2016 Kalem Eğitim ve Sağlık Hizmetleri Vakfı. Bütün Hakları Saklıdır. ISSN: 2146-5606
} 
parents of the public schools under the Ministry of National Education in Bahçelievler, Istanbul. The sample consists of 393 married couples. Marital Self-efficacy Scale, Marital Problem Solving Scale and personal information form were used in the study. A simple linear regression analysis was conducted in order to determine married individuals' problem solving skills predictive power regarding their marital self-efficacy. According to the simple linear regression analysis, problem solving skills were significant predictors of married couple's marital self-efficacy beliefs.

Keywords: Marital self-efficacy; Marital problem solving skills; Married individuals.

\section{Evli Bireylerin Algılanan Problem Çözme Becerilerinin Evliliklerine Yönelik Öz Yeterlik İnançlarını Yordaması}

$\ddot{O} z$

$\mathrm{Bu}$ araştırmanın amacı evli bireylerin evlilikte algılanan problem çözme becerilerinin evliliğe yönelik özyeterlik inançlarını ne derece yordadığını belirlemektir. Araştırma, betimsel bir araştırma olup ilişkisel tarama modeline uygun olarak düzenlenmiştir. Araştırmanın evreni, İstanbul ili Bahçelievler ilçesi Millî Eğitim Bakanlığı'na bağlı devlet okullarında çalışan ve bu okulların velisi olan evli bireylerden oluşmaktadır. Örneklemi, İstanbul ili Bahçelievler ilçesine bağl1 393 evli birey oluşturmuştur. Araştırmada ölçme aracı olarak Evlilikte Yetkinlik Ölçeği, Evlilikte Sorun Çözme Ölçeği ve kişisel bilgi formu kullanılmıştır. Evli bireylerin algılanan problem çözme becerilerinin evliliklerine yönelik özyeterlik inançlarını yordama gücünü belirlemek amacıyla basit doğrusal regresyon analizi yapılmıştır. Basit doğrusal regresyon analizi sonucunda algılanan problem çözme becerilerinin, evli bireylerin evlilikte özyeterlik inançlarını anlamlı şekilde yordadığı bulunmuştur.

Anahtar Kelimeler: Evlilikte özyeterlik; Evlilikte problem çözme becerisi; Evli bireyler.

\section{Introduction}

Family is the basis of the Turkish social structure and marriage forms the basis of the family structure. Marriage is a crucial organ of 
Turkish society. Marriage is a contract between two people of opposite sex signed with the aim of living together, sharing their experiences, making children and raising them. In addition, marriage is recognized as a legal relationship between a male and a female adult which imposes specific rights and obligations on them. It is a socially recognized that relationship is based on sustaining the breed (T.C. Ministry of Family and Social Policies, 2011). The family environment which emerges with marriage has major contributions to family members. Love, respect, trust, and communication provided in the family environment is crucial for family members. Family members meet their substantial needs such as loyalty, forming a sincere, warm and close relationship, having trust, gaining respect and love. The healthy relationship and effective behaviors that married couples show to each other throughout their marriage have significant effects on meeting the needs of family members interaction and communication between the couples forms the basis for the family life. Problems between the couples due to various reasons can arise during this interaction process. What is important to effectively solve these problems. The problems that occur between couples throughout marriage not only affects family members but also the mental health of the community (Bradbury, Fincham and Beach, 2000; Canel, 2007; Özgüven, 2000). Thus, it is important for couples to have healthy marriages, to improve their marital relationships and to overcome marital problems. Marital self-efficacy belief contributes to the marriage to advance in this direction (Mitchell, 2012). 
Marital self-efficacy belief is defined as the personal belief of a married individual that he or she can be successful in overcoming marital problems or that he or she can maintain the marital relationship. Marital self-efficacy belief is important for the nature and quality of a marriage (Arias, Lyons and Street, 1997; Cihan-Güngör, 2007; Mitchell, 2012). Bandura (1986) defines self-efficacy belief based on the social-cognitive theory as the belief of an individual to starting the behavior, which can influence the events of the setting, and maintaining it until getting results. In other words self-efficacy is the belief related to an individual's skill to think about possible conditions, to organize necessary activities and to successfully practice the activities he or she organized.

According to Bandura's (1986) social-cognitive theory, relationship self-efficacy is defined as the belief concerning the individual's skill to display behaviors which are necessary to successfully maintain and enhance a romantic relationship (Lopez and Lent, 1991; Shurts, 2004). Marital self-efficacy belief is defined as the personal belief regarding an individual's skill to maintain his or her marital relationship and to be successful in overcoming marital problems (Cihan-Güngör, 2007; Seabrook, 1997). Relationship self-efficacy and marital self-efficacy can be said to bear the same meaning. Relationship self-efficacy is related to evaluating romantic relationships such as dating, betrothal or engagement and marital self-efficacy is related to evaluating relationships that emerge with the marriage process. It can 
be said that self-efficacy belief is highly important for close relationships.

The concept of relationship self-efficacy emerged with the models introduced by Doherty (1981a, 1981b), Fincham and Bradbury (1987), Lopez and Lent (1991). In further studies, relationship self-efficacy was examined with various variables and it was suggested that it has a major role in close relationships (Arias et al., 1997; Cui, Fincham and Pasley, 2008; Dostal and Langhinrichsen-Rohling, 1997; Cihan-Güngör, 2007; Lopez, Morua and Rice, 2007; Mitchell, 2012; Riggio et al., 2011; Seabrook, 1997; Shurts, 2004; Thomas, 1998). Self-efficacy belief in romantic relationships influences the interaction with the spouse, the quality of the relationship and enables it to be long-lasting. While a high level of relationship self-efficacy belief increases the belief in successfully maintaining close relationships, a low level of relationship self-efficacy belief causes the individual to feel uneasy and incompetent about his or her relationship (Riggio et al., 2011). Family members and couples have a major influence of the increase in marital self-efficacy. General experiences, indirect experiences, social persuasion and psychological conditions that Bandura (1997) defined as sources that increase self-efficacy are also effective in increasing marital self-efficacy (Mitchell, 2012).

General experiences of an individual can highly affect the marital relationship. Personal involvement (which belongs to the present or the past depending on the individual) is considered in an individual's self-efficacy belief about a close relationship. Evaluating the close 
relationships with the people that one enters in is included under this title (Shurts, 2004). In order for individuals to make positive changes in their relationships, they have to overcome the obstacles which they encountered in the past. Couples should be able to enter into positive communications, make positive decisions, share resolutions, organize their plans and carry them out and share their success and failures through general experiences. Thus, communication skills, decision making skills and problem solving skills of an individual can improve. These skills can increase the success and sharing experiences of couples and can enable them to overcome failures (Mitchell, 2012).

Similarly, indirect experiences can influence an individual's marital life and marital self-efficacy belief. The individual can observe people who have close relationships in his or her environment. In relationship self-efficacy, individuals observing their family, the relationships between family members, the romantic relationships between their friends and in fact the media (TV, show programs, newspaper articles, internet websites) are among indirect experiences (Shurts, 2004). Because family members have similar characteristics, and by observing each other's successful behaviors they can take each other as an example and also believe that they can themselves display those behaviors. The same goes for couples as well. An individual who observes his or her spouses small successes can have a self-efficacy belief for similar behaviors (Mitchell, 2012). Together with positive interaction, couples taking each others' behaviors as models and believing that 
they will be successfully affect their self-efficacy beliefs as well as the their children's development.

Married couples can also display social persuasion behaviors towards each other. Social persuasion in relationship self-efficacy takes place with the spouse who the individual has a close relationship, with friends and family members. For example if a father constantly says "You will never marry a decent man" to his daughter, then this is a negative social persuasion and will negatively affect his daughter's self-efficacy belief. When the friends of the same girl say, "You can enter in good relationships with people and you won't have a difficulty in finding a boyfriend", then this social persuasion will boost her relationship self-efficacy belief (Shurts, 2004). Similarly, positive and encouraging words that couples say to each other will increase marital self-efficacy belief.

Psychological events that occur throughout marriage can be said to be crucial elements that affect marital self-efficacy belief. The emotional state of individuals, who experience depression due to negative relationships with their spouse, will affect their functionality in other areas and their relationship self-efficacy will decrease (Cihan-Güngör and Özbay, 2008; Shurts, 2004). The negative emotional state, which is due to various reasons, of an individual's psychology will be evident in other areas and the individuals self-efficacy belief in a relationship will be affected by this. Similarly, an individual's physiology which is in a positive emotional state can have positive effects on other areas (Shurts, 2004). Pajares (2002) states that for the self-efficacy belief to 
increase, negative emotional states need to be decreased. Also this will increase physical and emotional well-being. It can be said that the spouses having positive emotions increases their marital self-efficacy beliefs.

Studies have put forward that when self-efficacy belief in a relationship is high, expectation for problem solving (Doherty, 1981a, 1981b), relationship satisfaction (Cui et al., 2008; Lopez, et al., 2007; Lopez and Lent, 1991), adjustment to each other and relationship determination (Lopez and Lent, 1991), expectation for relationship success (Riggio et al., 2011), marital satisfaction (Arias et al., 1997; Mitchell, 2012) and marital determination (Arias et al., 1997) will be high as well. In addition, the individual having a low level of marital and relationship self-efficacy belief is believed to be related to conflicts being settled with ineffective resolutions (Doherty, 1981a, 1981b), with the individual feeling hopeless (Fincham and Bradbury, 1987) and anxious about the relationship (Riggio et al., 2011).

Happiness in marriage is related to relationship skills of couples and problem solving is a crucial relationship skill. According to studies on marital problem solving skills, effective problem solving skills in marital issues have a significant contribution to marital satisfaction (Erbek, Beştepe, Akar, Eradamlar and Alpkan, 2005). It is important for couples to avoid displaying negative expressions to each other while solving problems (Stanley and Trathem, 1994). Destructive and negative communication between couples are linked to decrease in marital quality and effectiveness and to increase in divorce rates (Bradbury et 
al., 2000; Birditt, Brown, Orbuch and McIlvane, 2010; Stanley, Markman and Whitton, 2002) Couples are not always expected to arrive at a consensus. However, reaching a common ground and seeking ways to arrive at a consensus is necessary for a healthy relationship (Canel, 2007; Rosen-Grandon, 1998). In short, with regards to effective problem solving behaviors displaying constructive behaviors such as cooperating, making a positive communication, arguing in a calm manner and actively listening are factors that increase the effectiveness in marriages (Akçabozan and Hatipoğlu-Sümer, 2013; Birditt et al., 2010; Hac1, 2011; Özen, 2006; Tallman and Hsiao 2004). Studies underline that adjustment in marriage increases when intra-family communication is more effective and when couples increase the search for positive solutions for conflicts (Ahmadi, Ashrafi, Kimiaee and Afzali, 2010; Akgün and Polat-Uluocak; 2010; Chiu, 1998; Ebenuwa-Okoh, 2008; Greef and De Bruyne, 2000; Güven, 2005; Hac1, 2011; Hünler and Gençöz, 2003; Karney and Bradbury, 1997; Malkoç, 2001; Özen, 2006; Sardoğan and Karahan; 2005; Winemiller and Mitchell, 1994; Woszidlo and Segrin, 2013).

With regards to the conflicts that emerge in marriages how problems are solved is one of the crucial factors that affect the marital process (Ahmadi et al., 2010; Bradbury et al., 2000; Hünler, 2002; Williamson, Hanna, Lavner, Bradbury and Karney, 2013; Woszidlo and Segrin, 2013). Marital self-efficacy also plays an effective role in how to resolve problems that occur during marriage (Lopez et al., 2007; Mitchell, 2012). When individuals believe they cannot successfully 
solve conflicts they have with their spouses, they will put less effort in finding a solution. Conflicts of individuals, who don't believe they can resolve them, can result with wrong or ineffective solutions. When the belief in solving problems that individuals encounter decreases, conflicts regarding these problems that occur between the couples increase and as a result of ineffective solutions and unsuitable relationships emerge (Cui et al., 2008). Thus, in order to effectively solve problems, it is crucial for individuals to have high self-efficacy beliefs in their relationships. When relationship self-efficacy beliefs of individuals increase, their beliefs in effectively solving problems that they encounter with their spouses increase as well (Doherty, 1981a, 1981b; Lopez et al., 2007; Thomas, 1998).

According to researches, marital and relationship self-efficacy beliefs are related to effective problem solving skills (Bradbury and Fincham, 1990; Cui et al., 2008; Doherty, 1981a, 1981b; Lam, 1998; Lopez et al., 2007; Mitchell, 2012; Thomas, 1998). However, no studies were conducted in Turkey that focused on examining the relationship between relationship self-efficacy belief and effective problem solving skills. For this reason, the relationship between marital problem solving skills and marital self-efficacy belief is examined in this research. Thus, the problem statement of the research is: Are perceived marital problem solving skills of married individuals significant predictors of their marital self-efficacy beliefs? 


\section{Method}

The relational screening model, which is a descriptive research method, was used in the study in order to predict married individuals' marital self-efficacies. Population and sample, data collection instruments and the process of the research were given below.

\section{Population and Sample}

The population consisted of married individuals who work in and were parents of the public schools under the Ministry of National Education in Bahçelievler, Istanbul during the 2012-2013 academic periods. Stratified sampling method was used in the study. In the stratified sampling method, if an excessive amount of clusters increase the sample significantly, and then component sampling can be done from each cluster (Karasar, 2010). Random disproportional cluster sampling and random disproportional component sampling methods were used respectively while choosing the samples. For the random disproportional cluster sample, 94 public schools under the Ministry of National Education in Bahçelievler, Istanbul were listed according to the Ministry of National Education's website (Ministry of National Education, n.d.). A total of 17 schools which were selected randomly constituted the cluster sample. A list of student parents and married workers in these schools were listed by resorting to the institutions. Individuals that were to be included in the sample were selected with the random component sampling method. Individuals who work in the instructions and ones who are student parents were listed separately throughout this process. Because the number of married individuals who work in 
schools were 236, all of the individuals who were listed from the cluster sampling were included before carrying out the component sampling. 236 married individuals were selected from the student parents list to equal with the other list. A total of 472 married individuals were selected with the stratified sampling method. All of the participants in the list were contacted but only 430 individuals wanted to participate in the study. After conducting the data collection instruments on 430 participants and controlling the data, 393 participants were observed to complete all the data. This sample group consisted of 393 married individuals who worked in and were student parents of the public schools under the Ministry of National Education in Bahçelievler, Istanbul.

Table 1. Frequency and Percentage Values of Participants in the Sample According to Demographic Variables

\begin{tabular}{lll}
\hline & $\mathbf{F}$ & $\mathbf{\%}$ \\
\hline 1.Relationship with the Institution & 201 & 51.1 \\
Worker & 192 & 48.9 \\
Parent & 296 & 75.3 \\
\hline 2. Gender & 97 & 24.7 \\
Female & & \\
Male & 252 & 64.1 \\
\hline 3. Age & 138 & 35.1 \\
Between 24-39 & 3 & 0.8 \\
Between 40-55 & & \\
Unanswered & 170 & 43.3 \\
\hline 4. Educational Level & & \\
Pre-License Education & 223 & 56.7 \\
(High and Secondary School Graduate) & & \\
Bachelor's Degree or & & \\
Post-Graduate Education & 90 & 22.9 \\
\hline 6. Duration of Marriage & 195 & 49.6 \\
1-6 years & 106 & 27 \\
7-15 years & 2 & 0.5 \\
\hline 16 years and more & 393 & 100 \\
\hline Unanswered & & \\
\hline Total &
\end{tabular}


Frequency and percentage values of participants of the sample according to demographic variables were given in Table 1. According to the relationship with the institution variable, 201 (51.1\%) married individuals work at school and 192 (48.9\%) married individuals were parents with a student that attends school. According to the gender variable, 296 (75.3\%) participants are female and 97 (24.7\%) participants are male. According to the age variable, 252 (64.1\%) participants are between the ages 24-39 and 138 (35.1\%) participants were between 40-55. $3(0.8 \%)$ participants did not state their age. According to the educational level variable, 170 (43.3\%) participants had pre-license degree and $223(56.7 \%)$ participants had bachelor's or postgraduate degree. According to life of marriage variable, 90 (22.9\%) participants were married for 1-6 years, 195 (49.6\%) participants for 7-15 years and $106(27 \%)$ participants for 16 or more years. $2(0.5 \%)$ participants did not state how long they have been married for.

\section{Data Collection Instruments}

Marital Self-Efficacy Scale: The Marital Self-Efficacy Scale introduced by Cihan-Güngör and Özbay (2008) is a paper-and-pencil inventory with a total of 33 items, two sub-dimensions and which requires the individual to make a self-assessment. Marital Self-Efficacy Scale is a 5 point Likert scale. The first sub-dimension consists of 19 items that measures the relationship with the spouse in marriage. The second sub-dimension consists of 14 items that measures the relationship with the close environment in marriage. It is conducted on individuals who live together during the marriage relationship. The lowest score that can 
be obtained from the scale is 33 and the highest score is 165 . High scores indicate that the individual has a high self-efficacy in his or her marital relationship. Along with the total score that can be obtained from the scale, one can also do scoring for each sub-dimension of the scale. There are no reverse items in the scale. For the reliability of the scale; internal consistency was evaluated for the overall scale and also for each sub-dimension separately. Cronbach $\alpha$ internal consistency coefficient was .96 for the overall scale. Internal consistency coefficients for the relationship with the spouse sub-dimension were .96 and .94 for the relationship with the close environment sub-dimension. The item-total correlations range between .52 and .77 (Cihan-Güngör and Özbay, 2008).

Marital Problem Solving Scale: The Marital Problem Solving Scale was introduced by Baugh, Avery and Sheets-Hawoth (1982) in order to determine married individuals' perceptions on their skills to solve problems they encounter throughout their marriage. The scale consists of 9 items and is a 7 point Likert scale. Internal consistency coefficient of the original scale was .95 and test-retest correlation coefficient was $.86(p<.001)$. There was a $p<.001$ significant difference between the upper and lower quartiles of the scale scores. For the scale validity, its correlation with Dyadic Adjustment Scale developed by Spainer (1976) was examined and a $\mathrm{r}=.61 ; p<.001$ point significant relationship was detected between the two scales. Hünler (2002) adapted the scale into the Turkish culture. The scale was translated into Turkish by three experts who graduated from Middle East Technical University, De- 
partment of Social Sciences and who knew both languages well. The scale which was rated as 7 point in the original form was transformed into a 5 point Likert scale. The highest score that can be obtained from the scale is 45 and the lowest score is 9. High scores indicate that the individual perceives him or herself successful with regards to marital solving marital skills. The alpha coefficient of the scale was .88 and item-total correlation ranges between .63 and .73. For the scale validity, its correlation with the Dyadic Adjustment Scale developed by Spainer (1976) and adapted into Turkish by Fışıloğlu and Demir (2000) was examined and a $\mathrm{r}=.51 ; p<.001$ point significant relationship was detected between the two scales (Hünler, 2002).

\section{Process}

For the data analysis, a simple linear regression analysis was conducted to analyze the data regarding "Relationship with the Spouse" and "Relationship with the Close Environment" sub-dimensions of the Marital Self-Efficacy Scale. To what extent married couple's total scores for the Marital Problem Solving Scale predict the "Relationship with the Spouse" and "Relationship with the Close Environment" sub-dimensions of the Marital Self-Efficacy Scale was determined. In this study; total scores of "Relationship with the Spouse" and "Relationship with the Close Environment" sub-dimensions of the Marital Self-Efficacy Scale were predictor variables and total scores of the Marital Problem Solving Scale were outcome variables. 


\section{Results}

First, descriptive statistics of survey data was given. Then the results of the correlation and regression analyses of Marital Self-Efficacy and Marital Problem Solving were presented.

Table 2. Means, Standard Deviations, Standard Error, Ranj, Minimum and Maximum Values of The Marital Self-Efficacy Scale Sub-Dimensions and Marital Problem Solving Scale Scores

\begin{tabular}{|c|c|c|c|c|c|c|c|}
\hline & $\mathbf{N}$ & $\overline{\mathrm{X}}$ & SS & $\mathrm{Sh}_{\overline{\mathrm{x}}}$ & Ranj & Min & $\operatorname{Max}$ \\
\hline $\begin{array}{l}\text { Relationship with the } \\
\text { Spouse Sub Scale }\end{array}$ & 393 & 79.43 & 13.04 & 0.66 & 66 & 29 & 95 \\
\hline $\begin{array}{l}\text { Relationship with the } \\
\text { Close Environment Sub } \\
\text { Scale }\end{array}$ & 393 & 57.82 & 10.98 & 0.55 & 52 & 18 & 70 \\
\hline $\begin{array}{l}\text { Total Score of Marital } \\
\text { Self-Efficacy Scale }\end{array}$ & 393 & 137.25 & 20.98 & 1.06 & 113 & 52 & 165 \\
\hline Problem Solving Scale & 393 & 36.65 & 6.71 & 0.34 & 36 & 9 & 45 \\
\hline
\end{tabular}

Table 2 shows the means, standard deviations, standard error, ranj, minimum and maximum values of the scales. Relationship with the Spouse Sub Scale's mean is 79.43 (ss=13.04). Relationship with the Close Environment Sub Scale's mean is 57.82 (ss=10.98). Marital Self-Efficacy Scale's mean is 137.25 (20.98). Problem Solving Scale's mean is 36.65 (ss=6.71).

There should be a statistical significant relationship between variables for a regression analysis (Büyüköztürk, 2011). Pearson Product-Moment Correlation analysis was conducted in order to examine 
the relationship between perceived marital problem solving skills and the relationship with spouse and close environment self-efficacy belief variables. Analysis results are given in Table 3.

Table 3. Correlation Coefficients between Marital Self-Efficacy Scale Sub-Dimensions and Marital Problem Solving Scale Scores

\begin{tabular}{lccc}
\hline & $\begin{array}{c}\text { Relationship } \\
\text { with } \\
\text { the Spouse }\end{array}$ & $\begin{array}{c}\text { Relationship } \\
\text { with the Close } \\
\text { Environment }\end{array}$ & $\begin{array}{c}\text { Problem } \\
\text { Solving }\end{array}$ \\
\hline $\begin{array}{l}\text { Relationship with } \\
\text { the Spouse }\end{array}$ & 1.00 & & \\
$\begin{array}{l}\text { Relationship with the } \\
\text { Close Environment }\end{array}$ & $0.52^{* * *}$ & 1.00 & \\
$\begin{array}{l}\text { Problem Solving } \\
* * p<.001\end{array}$ & $0.53^{* * *}$ & $0.40^{* *}$ & 1.00 \\
\hline
\end{tabular}

As can be seen in Table 3, according to the results of the Pearson Product-Moment Correlation analysis, which was conducted to determine correlation coefficients between the sub-dimensions of the Marital Self-Efficacy Scale and the scores of the Marital Problem Solving Scale; there was a moderate and positive statistical significant relationship between relationship with the spouse and relationship with the close environment $(\mathrm{r}=0.52 ; p<.001)$; relationship with the spouse and problem solving $(\mathrm{r}=0.53 ; p<.001)$; and relationship with the close environment and problem solving $(\mathrm{r}=0.40 ; p<.001)$. A simple regression analysis was conducted after relationships between the variables were detected.

Results of the simple linear regression analysis, conducted in order to determine whether the perceived problem solving skill was a 
significant predictor of the self-efficacy belief of relationships with the partner in marriage, were given on Table 4.

Table 4. Linear Regression Analysis Results on Predicting Marital Self-Efficacy Scale Relationship with the Spouse Scores According to Marital Problem Solving Scale Scores

\begin{tabular}{lccccccccc}
\hline Variable & B & $\begin{array}{c}\text { Standard } \\
\text { Error }\end{array}$ & $\mathbf{B}$ & $\mathbf{T}$ & $\boldsymbol{p}$ & $\mathbf{R}$ & $\mathbf{R}^{2}$ & $\mathbf{F}$ & $\boldsymbol{p}$ \\
\hline Constant & 41.52 & 3.10 & & 13.39 & .000 & 0.53 & 0.28 & 154.20 & .000 \\
$\begin{array}{l}\text { Marital } \\
\text { Problem } \\
\text { Solving }\end{array}$ & 1.03 & 0.08 & 0.53 & 12.41 & .000 & & & & \\
\hline
\end{tabular}

It was evident on Table 4 that according to the simple linear regression analysis, which was conducted to reveal the predictive power of "Relationship with the Spouse" scores of the Marital Self-Efficacy Scale regarding the Marital Problem Solving Scale scores, there was a significant relationship between the scores of the Marital Problem Solving Scale and the Relationship with the Spouse sub-dimension of the Marital Self-Efficacy Scale $\left(\mathrm{R}=0.532 ; \mathrm{R}^{2}=0.28\right)$. The predictive power of Marital Problem Solving Scale scores regarding the "Relationship with the Spouse" sub-dimension of the Marital Self-Efficacy Scale was statistically significant $(\mathrm{F}=154.200 ; \mathrm{df}=1$; $p<.001)$. The marital problem solving score explained $28 \%$ of the variance of the relationship with the spouse score.

Results of the simple linear regression analysis, conducted in order to determine whether the perceived problem solving skill is a 
significant predictor of the self-efficacy belief of relationships with the close environment in marriage, were given on Table 5.

Table 5. Linear Regression Analysis Results on Predicting Marital Self-Efficacy Scale Relationship with the Close Environment Scores According to Marital Problem Solving Scale Scores

\begin{tabular}{lccccccccc}
\hline Variable & $\mathbf{B}$ & $\begin{array}{c}\text { Standard } \\
\text { Error }\end{array}$ & $\mathbf{B}$ & $\mathbf{t}$ & $\boldsymbol{p}$ & $\mathbf{R}$ & $\mathbf{R}^{\mathbf{2}}$ & $\mathbf{F}$ & $\boldsymbol{p}$ \\
\hline Constant & 33.52 & 2.82 & & 11.88 & .000 & 0.405 & 0.16 & 76.48 & .000 \\
$\begin{array}{l}\text { Marital } \\
\begin{array}{l}\text { Problem } \\
\text { Solving }\end{array}\end{array}$ & 0.662 & 0.07 & 0.405 & 8.74 & .000 & & & & \\
\hline
\end{tabular}

It was evident on Table 5 that, according to the simple linear regression analysis, which was conducted to reveal the predictive power of "Relationship with the Close Environment" scores of the Marital Self-Efficacy Scale regarding the Marital Problem Solving Scale scores, there was a significant relationship between the scores of the Marital Problem Solving Scale and the "Relationship with the Close Environment" sub-dimension of the Marital Self-Efficacy Scale $\left(\mathrm{R}=0.405 ; \mathrm{R}^{2}=0.16\right)$. The predictive power of Marital Problem Solving Scale score regarding the "Relationship with the Close Environment" sub-dimension of the Marital Self-Efficacy Scale was statistically significant $(\mathrm{F}=76.488 ; \mathrm{df}=1 ; p<.001)$. The marital problem solving score explained $16 \%$ of the variance of the relationship with the close environment score. 


\section{Discussion}

According to the research findings, the perceived problem solving skill significantly predicted the marital self-efficacy belief for relationship with the spouse and the close environment. The marital problem solving score explains $28 \%$ of the variance of the relationship with the spouse score and the marital problem solving score explained $16 \%$ of the variance of the relationship with the close environment score. This finding suggests that the individuals' perception on having marital problem solving skills is effective in explaining the marital self-efficacy belief. However, no studies were found in Turkey that examines the relationship between married individuals' problem solving skills and marital self-efficacy beliefs.

The relationship between relationship self-efficacy belief and problems solving skills were explored in foreign studies (Bradbury and Fincham, 1990; Cui et al., 2008; Doherty, 1981a, 1981b; Lam, 1998; Lopez et al., 2007; Mitchell, 2012; Thomas, 1998). Findings of this research are in line with the results of these mentioned studies. The individuals with high self-efficacy beliefs are successful at attaining their goals, having problem solving skills, being patient and showing high level of performance (Bandura, 1977, 1986). The individuals with low self-efficacy beliefs have low self-perceptions regarding their skills (Bandura, 2001). They display ineffective marital problem solving behaviors (Bradbury, 1989). In short, it can be stated that problem solving skills are closely related to the concept of self-efficacy belief. 
In studies which examine the relationship between relationship self-efficacy and problem solving, it was detected that problem solving skills are crucial factors for the self-efficacy belief. Doherty (1981a, 1981b) states that self-efficacy expectations in relationships affect the attitudes during a conflict and that while high level of relationship self-efficacy enables marital problem solving, low level of relationship self-efficacy leads to ineffective problem solving. Cui et al. (2008) underline that relationship efficacy plays a crucial role in effectively settling a conflict and reaching relationship satisfaction. Thomas (1998) claimed that couples with high relationship efficacy are more successful at solving problems. Lopez et al. (2007) stated that a high level of relationship efficacy that individuals process enables them to solve conflicts effectively. Thus, in order to effectively solve problems, it is crucial for individuals to have high self-efficacy beliefs in their relationships. When relationship self-efficacy beliefs of individuals increase, their beliefs in effectively solving problems that they encounter with their partners increase as well (Doherty, 1981a, 1981b; Lopez et al., 2007; Thomas, 1998). All these studies are in line with the research findings. In other words, study results supported the finding that problem solving skills of individuals significantly predicted marital self-efficacy beliefs regarding the relationship with the spouse. There were no studies that explored the relationship between the individuals' self-efficacy beliefs regarding their relationship with the close environment and their marital problem skills. However, it is expected for individuals who believe that they have effective problem solving skills 
to have a high level of self-efficacy belief regarding their relationship with the close environment.

According to studies on marital problem solving skills, effective problem solving skills in marital issues have a significant contribution to marital satisfaction (Erbek et al., 2005). It is important for couples to avoid displaying negative expressions to each other while solving problems (Stanley and Trathem, 1994). Destructive and negative communication between couples is linked to the decrease in marital quality and effectiveness and to the increase in divorce rates (Bradbury et al., 2000; Birditt et al., 2010; Stanley, Markman and Whitton, 2002) Couples are not always expected to arrive at a consensus. However, reaching a common ground and seeking ways to arrive at a consensus is necessary for a healthy relationship (Canel, 2007; Rosen-Grandon, 1998). In short, with regards to effective problem solving behaviors; displaying constructive behaviors such as cooperating, making a positive communication, arguing in a calm manner and actively listening are factors that increase the effectiveness in marriages (Akçabozan and Hatipoğlu-Sümer, 2013; Birditt et al., 2010; Hac1, 2011; Özen, 2006; Tallman and Hsiao 2004). Studies underline that adjustment in marriage increases when intra-family communication is more effective and when couples increase the search for positive solutions for conflicts (Ahmadi et al., 2010; Akgün and Polat-Uluocak; 2010; Chiu, 1998; Ebenuwa-Okoh, 2008; Greef and De Bruyne, 2000; Güven, 2005; Hac1, 2011; Hünler and Gençöz, 2003; Karney and Bradbury, 1997; Malkoç, 
2001; Özen, 2006; Sardoğan and Karahan; 2005; Winemiller and Mitchell, 1994; Woszidlo and Segrin, 2013).

According to the research, there is a relationship between perceived problem solving skills of married individuals and their marital self-efficacy beliefs. Findings of this research are in line with the literature findings. From this point of view, it can be said that having effective problem solving skills is crucial for marital relationships. Married individuals can settle their marital issues more easily and effectively with their problem solving skills. Solving marital disagreements effectively will increase the belief of individuals to overcome their marital problems. In other words, marital self-efficacy beliefs of the individuals will increase. Thus, it can be said that having effective marital problem solving skills is a substantial variable for marital self-efficacy belief.

This study, whose purpose was to examine marital self-efficacy belief, was conducted on married individuals in Bahçelievler, Istanbul. New results can be obtained from data that are collected from new sample groups of new studies. In addition, the term self-efficacy has a history in Turkey but the term marital self-efficacy is rather new. It is believed to be beneficial and effective to examine the relationship between marital self-efficacy belief and various variables (such as relationship satisfaction, relationship adjustment, relationship stability). When researches are examined, it is obvious that there are no experimental studies in Turkey directed at increasing marital self-efficacy levels of married couples. Thus, it is believed that carrying 
out experimental studies will have major contributions to the field. Qualitative researches can be conducted to determine how our age, educational level, life of marriage, number of children, maltreatment of spouse, perceived relationship romance and getting along with the spouses family variables affect marital self-efficacy belief.

In the field of application, it is evident that marital self-efficacy belief has a major role in increasing marital effectiveness. Thus, practices aiming at increasing marital self-efficacy beliefs of married couples under the guidance of marriage and family counseling can be carried out. Such practices can be carried out through pre-marital preparation programs, oriented at young couples who are getting ready for marriage or selecting a spouse, as prohibitive measures that can help couples to improve their efficacy beliefs. In addition, based on the study findings, the fact that marital self-efficacy decreases at later ages can be considered while conducting studies on married couples over the age of 40. Having effective problem solving skills promotes a healthy and functional marriage. Thus, problem solving skills can be provided for couples under family counseling services. Findings of this study suggest that by providing effective problem solving skills, individuals' marital self-efficacy beliefs can be increased.

\section{Kaynakça}

Ahmadi, K., Ashrafi, S. M. N., Kimiaee, A. and Afzali, M. H. (2010). Effect of family problem solving on marital satisfaction. Journal of Applied Sciences, 10(8), 682-687.

Akçabozan, N. B. and Hatipoğlu-Sümer, Z. H. (2013). The role of 
conflict handling behaviours and personality traits on marital satisfaction. In İstanbul 2013 World Congress of Psychological Counselling and Guidance (pp.318-319). İstanbul: Boğaziçi Üniversitesi.

Akgün, R. and Polat Uluocak, G. (2010). Effective communication and problem solving for marriage: A group work with women in a community center. Aile ve Toplum Eğitim Kültür ve Araştırma Dergisi, 6(23), 9-22.

Arias, I., Lyons, C. M. and Street, A. E. (1997). Individual and marital consequences of victimization: Moderating effects of relationship efficacy and spouse support. Journal of Family Violence, 12(2), 193-210.

Bandura, A. (1977). Social learning theory. Englewood Cliffs, New Jersey: Prentice-Hall.

Bandura, A. (1986). Social foundations of thought and action. Englewood Cliffs, New Jersey: Prentice-Hall.

Bandura, A. (1997). Self-efficacy: The exercise of control. New York: Freeman Company.

Bandura, A. (2001). Social cognitive theory: An agentic perspective. Annual Reviews Psychology, 52, 1-26.

Baugh, C. W., Avery, A. W. and Sheets-Haworth, K. L. (1982). Marital problem solving scale: A measure to assess relationship conflict negotiation ability. Family Therapy, 9, 43-51.

Bradbury, T. N. (1989). Cognition, emotion and interaction in distressed and nondistressed couples. Unpublished $\mathrm{PhD}$ Thesis, University of Illinois. 
Bradbury, T. N. and Fincham, F. D. (1990). Attributions in marriage: Review and critique. Psychological Bulletin, 107(1), 3-33.

Bradbury, T. N., Fincham, F. D. and Beach, S. R. (2000). Research on the nature and determinants of marital satisfaction: A decade in review. Journal of Marriage and Family, 62(4), 964-980.

Birditt, K. S., Brown, E., Orbuch, T. L. and McIlvane, J. M. (2010). Marital conflict behaviors and implications for divorce over 16 years. Journal of Marriage and Family, 72(5), 1188-1204.

Büyüköztürk, Ş. (2011). Sosyal bilimler için veri analizi el kitabı. Ankara: Pegem Akademi.

Canel, A. N. (2007). Ailede problem çözme, evlilik doyumu ve örnek bir grup çalışmasının sınanması. Unpublished PhD Thesis, Marmara Üniversitesi.

Cihan-Güngör, H. (2007). Evlilik doyumunu açıklamaya yönelik bir model geliştirme. Unpublished PhD Thesis, Gazi University.

Cihan-Güngör, H. and Özbay, Y. (2008). Evlilikte yetkinlik ölçeğinin geçerlik ve güvenirlik çalışması. Türk Psikolojik Danışma ve Rehberlik Dergisi, 3(29), 79-90.

Chiu, R. K. (1998). Relationships among role conflicts, role satisfactions and life satisfaction: Evidence from Hong Kong. Social Behavior and Personality, 26(4), 409-414.

Cui, M., Fincham F. D. and Pasley, B. K. (2008). Young adult romantic relationships: The role of parents' marital problems and relationship efficacy. Society for Personality and Social Psychology, 34(9), 1226-1235.

Doherty, W. J. (1981a). Cognitive processes in intimate conflict: I Extending attribution theory. The American Journal of Family 
Therapy, 9(1), 3-13.

Doherty, W. J. (1981b). Cognitive processes in intimate conflict: II Efficacy and learned helplessness. The American Journal of Family Therapy, 9(2), 35-44.

Dostal, C. and Langhinrichsen-Rohling, J. (1997). Relationship-specific cognitions and family of origin divorce and abuse. Journal of Divorce and Remarriage, 27, 101-120.

Ebenuwa-Okoh, E. E. (2008). Personality variables as correlates of marital adjustment among married persons in Delta State of Nigeria. Educational Research and Review, 3(8), 275-279.

Erbek, E., Beştepe, E., Akar, H., Eradamlar, N. and Alpkan, R. L. (2005). Evlilik uyumu. Düşünen Adam, 18(1), 39-47.

F1şıloğlu, H. and Demir, A. (2000). Applicability of dyadic adjustment scale for measurement of marital quality with Turkish couples. European Journal of Psychological Assessment, 16(3), 214-218.

Fincham, F. D. and Bradbury, T. N. (1987). Cognitive processes and conflict in close relationships: An attribution-efficacy model. Journal of Personality and Social Psychology, 53(6),1106-1118.

Greef, A. P. and De Bruyne, T. (2000). Conflict management style and marital satisfaction. Journal of Sex and Marital Satisfaction, 26(4), 321-334.

Güven, N. (2005). Ilişskilerle ilgili bilişsel çarpıtmalar ve evlilikte problem çözme becerilerinin evlilik doyumu ile ilişkisi. Unpublished master's thesis, Ankara Üniversitesi.

Hacı, Y. (2011). Evlilik uyumunun empatik eğilim, algllanan aile içi iletişim ve çatışma çözme stillerine göre yordanması. Unpublished master's thesis, Ege Üniversitesi. 
Hünler, O. S. (2002). The effects of religiousness on marital satisfaction and the mediator role of perceived marital problem solving abilities between religiousness and marital satisfaction relationship. Unpublished master's thesis, ODTÜ.

Hünler, O. S. and Gençöz, T. (2003). Boyun eğici davranışlar ve evlilik doyumu ilişkisi: Algılanan evlilik problemleri çözümünün rolü. Türk Psikoloji Dergisi, 18(51), 99-108.

Karasar, N. (2010). Bilimsel araştırma yöntemi. Ankara: Nobel Yayın Dağıtım.

Karney, B. R. and Bradbury, T. N. (1997). Neuroticism, marital interaction, and the trajectory of marital satisfaction. Journal of personality and social psychology, 72(5), 1075-1092.

Lam, J. H. (1998). Self-efficacy and coping responses in lower socioeconomic status African-American women involved in abusive relationships. Unpublished $\mathrm{PhD}$ thesis, Syracuse University.

Lopez, F. G. and Lent, R. W. (1991). Efficacy-based predictors of relationship adjustment and persistence among college students. Journal of College Student Development, 32, 223-229.

Lopez, F. G., Morua W. and Rice K. G. (2007). Factor structure, stability, and predictive validity of college students' relationship self-efficacy beliefs. Measurement and Evaluatian in Counseling and Development, 40, 80-96.

Malkoç, B. (2001). The relationship between communication patterns and marital adjustment. Unpublished master's thesis, ODTÜ.

Ministry of National Education. (n.d.). Milli e ğitim bakanlı̆̆ına bă̆ll kurumlar listesi. Retivered March 6, 2013, http://www.meb.gov.tr/baglantilar/okullar/index.asp?ILKODU= 34\&ILCEKODU $=28$. 
Mitchell, J. K. (2012). Marital dining practices: Affecting change in marital satisfaction through marital self-efficacy. Unpublished PhD Thesis, University of George Fox.

Özen, A. (2006). Value similarities of wives and husbands and conflict resolution styles of spouses as predictors of marital adjustment. Unpublished Master Thesis, Middle East Technical University.

Özgüven, İ. E. (2000). Evlilik ve aile terapisi. Ankara: PDREM Yayınları.

Pajares, F. (2002). Overview of social cognitive theory and of self-efficacy. Retivered June, 25, 2013, http://www.uky.edu/ eushe2/Pajares/eff.html.

Riggio, H. R., Weiser, D., Valenzuela, A., Lui, P., Montes, R. and Heuer, J. (2011). Initial validation of a measure of self-efficacy in romantic relationships. Personality and Individual Differences, 51, 601-606.

Rosen-Grandon, J. R. (1998). The relationship between marital characteristics, marital interaction process and marital satisfaction. Unpublished $\mathrm{PhD}$ Thesis, University of North Carolina.

Sardoğan, M. E. and Karahan, T. F. (2005). Evli bireylere yönelik bir insan ilişkileri beceri eğitimi programının evli bireylerin evlilik uyum düzeylerine etkisi. Ankara Üniversitesi Eğitim Bilimleri Fakültesi Dergisi, 38(2), 89-102.

Seabrook, M. K. (1997). The application of social cognitive theory to the intergenerational transmission of divorce. Unpublished $\mathrm{PhD}$ Thesis, University of California.

Shurts, W. M. (2004). The relationships among marital messages received, marital attitudes, relationship self-efficacy, and wellnes among never married traditional aged undergraduate students. 
Unpublished $\mathrm{PhD}$ Thesis, University of North Carolina.

Spainer, G. B. (1976). Measuring dyadic adjustment: New Scale for assessing the quality of marriage and similar dyads. Journal of Marriage and the Family, 38, 15-28.

Stanley, S. M. and Trathen, D. W. (1994). Christian PREP: An empirically based model for marital and premarital intervention. Journal of Psychology and Christianity, 12, 158-165.

Stanley, S. M., Markman, H. J. and Whitton, S. W. (2002). Communication, conflict, and commitment: Insights on the foundations of relationship success from a national survey. Family Process, 41(4), 659-675.

Tallman, I. and Hsiao, Y. L. (2004). Resources, cooperation, and problem solving in early marriage. Social Psychology Quarterly, 67(2), 172-188.

T. C. Ministry of Family and Social Policies. (2011). Research on family structure in Turkey 2011. Retrieved October 10, 2013, http://www.ailetoplum.gov.tr/upload/athgm.gov.tr/mce/2013/tay a_kitap_butun.pdf.

Thomas, J. M. (1998). Relationship efficacy: The prediction of goal attainment by dating couples. Unpublished Doctoral Thesis, University of Maryland.

Williamson, H. C., Hanna, M. A., Lavner, J. A., Bradbury, T. N. and Karney, B. R. (2013). Discussion topic and observed behavior in couples' problem-solving conversations: Do problem severity and topic choice matter? Journal of Family Psychology, 27(2), 330-335.

Winemiller, D. R. and Mitchell, M. E. (1994). Development of a coding system for marital problem solving efficacy. Behaviour Research 
and Therapy, 32(1), 159-164.

Woszidlo, A. and Segrin, C. (2013). Direct and indirect effects of newlywed couples' neuroticism and stressful events on marital satisfaction through mutual problem solving. Marriage and $\mathrm{Fa}$ mily Review, 49(6), 520-545. 